\title{
Optimalisasi Pokdarwis Massawi Melalui Tourism Service Management Pengembangan Objek Wisata Teluk Love Jember
}

\author{
Aryo Prakoso ${ }^{1}$, Margaretta Andini Nugroho², Rebecha Prananta ${ }^{3}$ \\ ${ }^{1}$ Program Studi DIII Perpajakan, Universitas Jember \\ ${ }^{2,3}$ Program Studi DIII Usaha Perjalanan Wisata, Universitas Jember \\ Email : ${ }^{1}$ Aryo.fisip@unej.ac.id, ${ }^{2}$ margaretta@unej.ac.id, ${ }^{3}$ Prananta.rebecha@gmail.com
}

\section{INFORMASI ARTIKEL}

\section{Data artikel:}

Naskah masuk, 10 Desember 2019

Direvisi, 26 Desember 2019

Diiterima, 16 Januari 2020

\section{Kata Kunci:}

Objek Wisata

Tourism Service Management Optimalisasi

\begin{abstract}
ABSTRAK
Abstract- Jember has a very diverse natural, cultural and artificial tourism potential. One of the natural potentials that currently become the prima donna in Jember is Teluk Love beach, located in Sumberrejo-Ambulu-Jember. The main attraction of the Love Bay is in terms of its shape that symbolizes love, which is not possessed by other destinations in Jember. The booming existence of the Love Bay increases tourist arrivals at this destination every day, in the other hand the condition of human resources and social economic environment is not ready to face of the growth of Love Bay tourism. Weak tourism knowledge, slum social environment patterns, society economic management are some challenges in developing this Love Bay tourism. Theoretically, if a tourist destination is well managed, tourists as subjects in the tourism industry have an important role in the sustainability of a tourist destination. The tourist services needs to get special attention. If the tourists are well served, then they will feel satisfied. This is a factor driving these tourists to come back, and with the more tourists it will have an effect on improving the economic level of the community itself. Based on the problems experienced by partners, the solutions that can be offered are providing soft skills training (attitude) for tourism services, providing hard skills training (procedural), providing assistance in the form of procurement of quality improvement service.
\end{abstract}

Abstrak- Kabupaten Jember memiliki potensi wisata yang
sangat beragam, baik potensi wisata alam, budaya maupun
buatan. Salah satu potensi alam yang saat ini menjadi
primadona di Kabupaten Jember adalah pantai Teluk Love,
yang terletak di Desa Sumberrejo, Kecamatan Ambulu,
Kabupaten Jember. Daya tarik utama dari Teluk Cinta adalah
dari segi bentuknya yang melambangkan simbol cinta, yang
tidak dimiliki oleh destinasi lain di Kabupaten Jember.
Keberadaan Teluk Cinta yang semakin booming meningkatkan
kedatangan wisatawan di tujuan ini setiap hari, tetapi memiliki
kondisi yang kontras dengan sumber daya manusia dan
lingkungan sosial ekonomi yang tidak siap dalam menghadapi
pertumbuhan pariwisata Teluk Cinta. Pengetahuan Pariwisata
yang Lemah, pola lingkungan sosial kumuh, pengelolaan


ekonomi masyarakat merupakan tantangan dalam mengembangkan pariwisata Teluk Cinta ini. Secara teoritis, jika tujuan wisata dikelola dengan baik, wisatawan sebagai subjek dalam industri pariwisata memiliki peran penting dalam keberlanjutan tujuan wisata, perlu mendapat perhatian khusus dalam melayani wisatawan. Layanan kepada wisatawan dilayani dengan baik, maka wisatawan akan merasa puas, ini adalah faktor yang mendorong para wisatawan ini untuk kembali dengan lebih banyak khalayak dan semakin banyak wisatawan akan berdampak pada peningkatan tingkat ekonomi masyarakat itu sendiri. Berdasarkan masalah yang dialami oleh mitra, solusi yang dapat ditawarkan adalah memberikan pelatihan keterampilan (sikap) lunak untuk layanan pariwisata, memberikan pelatihan keterampilan keras (prosedural atau manajemen) untuk layanan pariwisata, memberikan bantuan dalam bentuk pengadaan layanan peningkatan kualitas.

\section{Korespondensi:}

\section{Aryo Prakoso}

Program Studi DIII Perpajakan, Universitas Jember

Jl. Kalimantan No. 37, Krajan Timur, Sumbersari, Jember, Jawa Timur, Indonesia

\section{PENDAHULUAN}

Pariwisata merupakan sebuah bisnis yang menjanjikan dan dapat meningkatkan pendapatan daerah setempat (Cooper \& Hall, 2008). Objek wisata Teluk Love terletak dikawasan Pantai Payangan Desa Sumberejo Kecamatan Ambulu Kabupaten Jember. Berdasarkan Badan Pusat Statistik Kabupaten Jember Tahun 2016, jumlah Penduduk Desa Sumberejo adalah 24.611 jiwa yang terdiri dari 12.309 laki-laki dan 12.302 perempuan. Sebagian besar dari mata pencaharian penduduknya adalah sebagai nelayan.

Apabila dilihat dari data, 46,21\% atau hampir mencapai setengahnya masyarakat menggantungkan hidupnya dari mencari ikan. Kondisi ekonominya pun bisa dikatakan tergolong rendah jika dibandingkan dengan kondisi perekonomian dari desa lain yang berdekatan, seperti Sabrang, Tanjung Rejo dan Silir. Sebelum Pantai Payangan mulai dikenal penduduk, Desa Sumberejo Desa Sumberrejo yang merupakan salah satu desa tematik pengembangan desa wisata, Pantai Payangan ini merupakan pantai nelayan yang hanya dimanfaatkan untuk mencari ikan yang kemudian hasil tangkapan ikan ini dibeli secara langsung oleh masyarakat. Adapun wilayah teluk love dahulu merupakan area pembuangan sampah dan memiliki lingkungan yang kurang sehat. Kondisi tersebut kemudian berangsur berubah ketika kemudian ada gerakan sadar wisata yang dipelopori oleh tokoh masyrakat setempat. Untuk menggali lebih dalam potensi Pantai Payangan untuk kegiatan wisata, tokoh masyarakt ini membuat sebuah kelompok sadar wisata atau Pokdarwis yang diberi nama Massawil (Masyarakat Sadar Wisata Lestari Bahari). Potensi Pantai Payangan menawarkan daya tarik keindahan pasir pantai dan air lautnya yang bersih dan biru, selain itu di kawasan pantai ini juga memiliki daya tarik lainnya yaitu mempunyai 3 bukit yang indah, yaitu bukit Sruni, bukit Samboja dan bukit Domba. Bukit Domba inilah yang menjadi memiliki daya tarik sangat kuat untuk lebih dikembangkan, karena bentuk bibir laut jika dilihat dari Bukit Domba terlihat seperti lambang hati.

Potensi lebih dalam di Bukit Domba ini, dimana bibir pantai yang berbentuk hati diberi nama Teluk Love. Selain itu terdapat atraksi 
wisata lain di Bukit Domba yaitu Gua Jepang, Puncak Nirwana dan Raja A Empat. Setelah mengembangkan daerah Teluk Love, semakin banyak wisatawan yang datang berkunjung. Hingga saat ini bisa dikatakan pamor Teluk Love Pantai Payangan sudah mengalahkan Pantai Watu Ulo dan Pantai Papuma. Wisatawan yang datang saat ini sangat ramai, berasal dari berbagai daerah, terutama di saat hari libur.

Pengembangan objek wisata Teluk Love Pantai Payangan yang dilakukan oleh tokoh masyarakat yang berjalan tidak diiringi dengan pengembangan sumber daya manusianya. Seperti yang kita ketahui bahwa masyarakat di sekitar Teluk Love adalah nelayan yang tidak memahami tentang kepariwisataan. Mayoritas tingkat pendidikannya pun hanya lulusan SD dan SMP. Hal ini menyebabkan respon masyarakat sekitar terhadap ramainya kedatangan wisatawan masih sangat kurang. Sikap masyarakat terhadap wisatawan masih acuh, kurang ramah dan terkesan kurang peduli. Padahal masyarakat sudah merasakan dampak ekonomi yang positif dari kegiatan pariwisata di Teluk Love Pantai Payangan. Mereka kurang sadar bahwa keberadaan wisatawan memiliki peran penting dalam keberlangsungan pariwisata di Teluk Love. Melihat hal ini maka perlu diberikan pengarahan mengenai sadar wisata kepada masyarakat nelayan di Teluk Love Pantai Payangan, seperti upaya menjadi sebuah daerah wisata sapta pesona (Savitri, 2018; Septio et al., 2019).

Untuk meningkatkan kedatangan wisatawan maka perlu ditingkatkan juga kepuasan wisatawan saat berwisata. Semakin meningkat wisatawan yang datang, maka semakin meningkat pula dampak ekonomi yang dirasakan masyarakat. Cooper (2010) Salah satu cara untuk meningkatkan kepuasan wisatawan adalah dengan memberikan pelayanan yang maksimal kepada wisatawan selama berwisata di Teluk Love. Masyarakat perlu diberikan pelatihan soft skill pariwisata agar dapat memberikan pelayanan yang mampu memuaskan wisatawan untuk meningkatkan kedatangan wisatawan ke Teluk Love Pantai Payangan.Untuk mendukung pelayanan prima kepada wisatawan, tampilan dari pengelola Teluk Love juga perlu diperhatikan, agar menjadi identitas yang membedakan antara pengelola dan pengunjung. Selain itu juga bisa menciptakan kesan rapi dan indah, yang membuat wisatawan merasa nyaman. Oleh karena itu diperlukan bantuan untuk memberikan seragam kepada pengelola Teluk Love Payangan.

Selain itu, permasalahan lain yang muncul adalah dalam segi manajemen pengelolaan Teluk Love, belum adanya perencanaan, pengawasan, dan pengarahan dalam pengembangan pariwisata dalam kelompok sadar wisata MASSAWIL. Padahal hal ini perlu dilakukan untuk mencapai target maupun visi misi yang ingin dicapai. Oleh karena itu perlu diberikan pelatihan hard skill pariwisata adar dapat mengelola kegiatan pariwisata Teluk Love Pantai Payangan lebih baik lagi.

\section{METODE PELAKSANAAN}

Metode pelaksanaan yang digunakan dalam program pengabdian ini dilakukan dengan beberapa metode, antara lain:

a) Survei

Metode survei dalam program pengabdian kemitraan pada masyarakat dilaksanakan untuk melakukan kegiatan observasi dan identifikasi untuk mengetahui potensi sumber daya manusia pariwisata yang ada di Pantai Payangan atau PantaiTeluk Love. Perlu untuk diketahui, sebagian besar sumber daya manusia yang berada di Pantai Teluk Love desa Sumberejo Kecamatan Ambulu. Dalam kegiatan survey, dilakukan wawancara mendalam kepada Ketua Kelompok Sadar Wisata (POKDARWIS) MASSAWI.

b) Presentasi atau Ceramah

Presentasi dilakukan dihadapan perwakilan masyarakat, tokoh desa, perangkat 
desa, dan anggota POKDARWIS. Presentasi atau ceramah dimaksudkan untuk penyampaian materi mengenai kepariwisataan, dasar - dasar pariwisata, pelayanan kepariwisataan dan manajemen organisasi pariwisata, hal ini bertujuan agar masyarakat lebih memahami konsep pelayanan kepariwisataan itu seperti apa sehingga kedepannya masyarakat sudah memiliki keahlian dalam melayani wisatawan. Dalam sesi ini juga disampaikan mengenai program-program kegiatan yang akan dilakukan selama program pengabdian yang dilaksakan selama 2 bulan. Setelah sesi penyampaian materi, masyarakat diajak untuk tanya jawab dan berdiskusi bersama.

\section{c) Pelatihan}

Metode pelatihan dilaksanakan dalam rangka memberikan contoh secara langsung dari materi yang sudah diberikan dalam sesi presentasi. Pelatihan dalam pengabdian ini terdiri dari pelatihan soft skill pariwisata yaitu dasar pelayanan pariwisata yang terdiri pelatihan 5S dan pelatihan sapta pesona. Selain itu juga terdapat pelatihan hard skill yang berisi tentang pelatihan manajemen organisasi kepariwisataan.

\section{d) Pendampingan}

Setelah dilakukan pelatihan, pihak pengabdi juga melakukan program pendampingan untuk mendukung pengembangan desa wisata di Pocangan. Pendampingan ini dilakukan dengan evaluasi terhadap proses pelaksanaan pelayanan kepariwisataan dan manajemen organisasi, selain itu pendampingan juga dilaksanakan dengan memberikan kontribusi pada "human packaging" dan "spot selfie packaging" di Teluk Love.

\section{HASIL DAN PEMBAHASAN}

\subsection{Sumber Daya Manusia Pariwisata Teluk Love}

Dalam kunjungan yang pertama dan kedua tim pengabdian melakukan observasi dan wawancara mendalam untuk mengetahui potensi sumber daya manusia pariwisata yang ada di Pantai Payangan atau PantaiTeluk Love. Perlu untuk diketahui, sebagian besar sumber daya manusia yang berada di Pantai Teluk Love desa Sumberejo Kecamatan Ambulu merupakan masyarakat dengan latar belakang mata pencaharian sebagai nelayan, dengan rata-rata adalah lulusan SD dan SMP.

Berdasarkan data yang ditemukan tersebut, sumber daya manusia yang mengelola bukanlah sumber daya manusia pariwisata yang profesional, karena memang pada awalnya pantai Teluk Love atau yang lebih dikenal dengan pantai Payangan bukanlah pantai yang dikhususkan untuk pariwisata, melainkan pantai yang digunakan nelayan untuk mencari ikan dan terkadang digunakan sebagai tempat transaksi penjualan ikan hasil tangkapan antara nelayan dan pembeli, sehingga memang sumber daya manusianya sama sekali tidak memahami tentang pariwisata dan segala bentuk kegiatannya. Penggambaran framework kegiatan pengabdian yang dilaksanakan seperti diperlihatkan pada Gambar 1.

\section{SDM Soft skill Hard skill Packaging}

Gambar 1. Framework Pengabdian Masyarakat

Awal terbentuknya pantai Payangan menjadi pantai yang dikelola untuk pariwisata, digagas oleh Pak Suto. Dimana dalam proses pembenahan pantai Payangan, beliau menggagas untuk membentuk kelompok sadar wisata MASSAWI atau masyarakat sadar wisata bahari, dimana anggota dari pokdarwis ini berasal dari mayarakat sekitar yang memiliki keinginan yang sama untuk membuat pantai payangan bukan hanya sebagai pantai penghasil ikan tetapi juga sebagai pantai untuk pariwisata. Pak suto bersama pokdarwis berperan cukup besar dalam menata ulang dan memanfaatkan potensi alam yang dimiliki Payangan untuk bisa dinikmati wisatawan, mulai dari pembersihan pantai, penghijauan lokasi pantai, hingga kini sudah terdapat pintu 
masuk pantai, tempat bersantai, fasilitas kamar mandi, mushola, tempat makan hingga spot selfie.

Berbagai fasilitas yang semakin diperbaiki memberikan dampak yang sangat postif dengan semakin meningkatknya wisatawan yang datang ke Pantai Payangan, terlebih dengan ditemukannya spot pantai payangan yang jika dilihat dari atas terlihat seperti bentuk hati atau love. Wisatawan yang datang begitu penasaran untuk bisa mengambil gambar dari spot ini, sehingga semenjak saat itu pantai Payangan lebih terkenal dengan sebutan Pantai Teluk Love. Munculnya Teluk Love pun semakin menambah jumlah kunjungan wisatawan.

Semakin ramainya kedatangan wisatawan sebenarnya juga direspon sangat baik oleh masyarakat sekitar, karena ternyata dari aktivitas kepariwisataan tersebut bisa menambah pendapatan perekonomian kepada masyarakat sekitar melalui penjualan makanan minuman dan tempat parkir. Permasalahan timbul karena masyarakat atau sumber daya manusia yang berada di sekitar Teluk Love bukanlag SDM pariwisata yang profesional, mereka tidak mengetahui bagaimana cara membuat wisatawan saat berkunjung merasa aman, nyaman dan terpuaskan. Masyarakat masih belum sadar wisata, sehingga masyarakat memperlakukan wisatawan sekedarnya. Bahkan terkesan kurang menyenangkan, terlebih ketika mereka menawarkan lahan tanahnya yang dijadikan parkir kepada wisatawa yang datang. Mereka dengan nada yang agak tinggi memaksa wisatawan ini untk memarkirkan kendaaraan dilahan mereka, masyarakat yang satu dengan lainnya saling berebutan wisatawan. Tentunya hal ini membuat wisatawan merasa takut dan sangat tidak nyaman.

Kondisi sumber daya manusia ini harus diperbaiki dan dirubah, mengingat kepuasan wisatawan saat berkunjung akan menentukan wiatawan tersebut akan kembali ke Teluk Love atau tidak, dan juga akan mempengaruhi penilaian wisatawan yang nantinya penilaian tersebut akan mereka bagikan kepada kerbat dan teman-temannya, jika penilaian yang dihasilkan negatif tentunya akan berpengaruh buruk terhadap Teluk Love kedepannya. Berdasarkan hasil observasi ini, tim pengabdian memutuskan membuat pelatihan yang khusus untuk meningkatkan soft skill dan hard skill pariwisata kepada masyarakat Pantai Payangan.

\subsection{Pelatihan Soft Skill Sumber Daya Manusia Teluk Love}

Berdasarkan informasi yang dadapatkan dari hasil kunjungan pertama dan kedua ke Teluk Love, kunjungan ketiga tim pengabdian datang untuk melaksanakan pelatihan soft skill pariwisata yang berhubungan dengan pelatihan dalam memberikan pelayanan ke wisatawan, agar masyarakat atau sdm yang ada bisa menjadi SDM pariwisata. Hal pertama yang harus dilakukan adalah mebuat SDM tersebut sadar wisata. Sadar wisata adalah sebuah kondisi dimana masyarakat memahami betul arti pariwisata bagi mereka, pelatihan yang bisa dilakukan untuk menjadikan masyarakat Teluk Love menjadi masyarakat yang sadar wisata, adalah dengan melakukan pelatihan dasar pelayanan pariwisata yang terdiri dari pelatihan 5S dan pelatihan sadar wisata.

\subsection{Pelatihan 5S}

Pelatihan 5S adalah pelatihan yang mempelajari tentang bagaimana memberikan pelayanan kepada wisatawan dengan bisa melakukan dasar pelayanan yang terdiri dari Salam, Sapa, Senyum, Sopan dan Sentuh (Sukarni, 2019). 5 bentuk dasar pelayanan ini harus dipahami oleh masyarakat dan harus bisa diterapkan dalam keseharian setiap bertemu dengan wisatawan. Oleh karena itu dalam pelatihan yang dilakukan, tim bekerja sama dengan pokdarwis mengundang masyarakat sekitar untuk mengikuti pelatihan 5S. Pelatihan yang dilaksanakan terdiri dari pemaparan materi, praktek kemudian evaluasi. Materi yang diberikan yaitu diberikan dengan istilah Salam, Sapa, Senyum, Sopan, dan Sentuh (5S). 
Selama ini baik masyarakat dan pokdarwis belum cukup mampu untuk memberikan salam yang baik kepada wisatawan. Salam yang dimaksud adalah menegur wisatawan yang datang dengan mengucapkan kalimat sapaan. Contoh kalimat sapaan adalah sebagai berikut : Selamat Pagi, Selamat siang, selamat datang. Kalimat sapaan ini lebih baik disampaikan dengan ciri khas objek wisata tersebut, agar memberikan kenangan yang mengesankan kepada wisatawan. Dalam memberikan salam juga harus memperlihatkan gestur tubuh, ekspresi wajah dan nada suara yang memberikan kesan nyaman kepada wisatawan. Untuk Pantai Teluk Love, tim berhasil membuat Salam yang berciri khas Teluk Love, yaitu dengan mengucapkan "Selamat Pagi, Selamat Datang di Teluk Love" dengan membuat gerakan tangan membentuk hati atau love. Salam ini harus dilakukan oleh seluruh SDM Teluk Love yang bertemu wisatawan, terutama SDM yang berada di lokasi teluk love, seperti penjaga loket tiket masuk. Gestur salam ini bisa dilihat digambar dibawah ini.

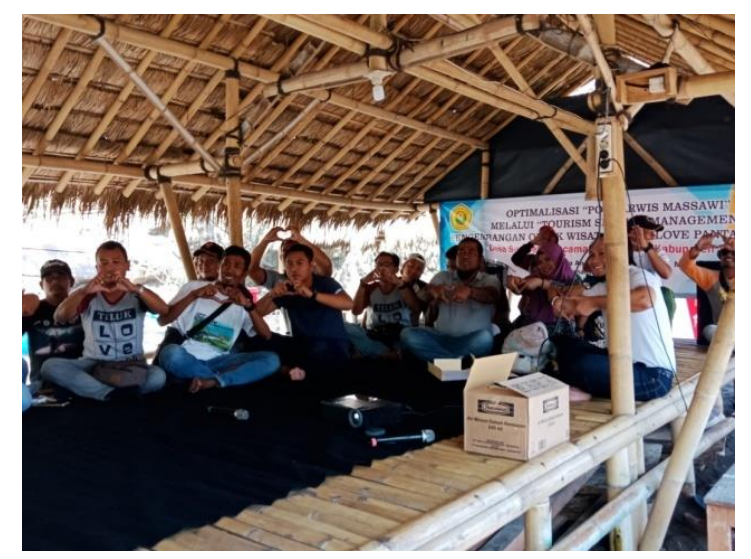

Gambar 2. Melakukan Salam dengan Membentuk Tanda "Love"

Setelah mengucapkan salam kepada wisatawan, pihak sdm pariwisata juga harus memberikan sapa. Perbedaannya salam dengan sapa yaitu, salam diberikan kepada wisatawan ketika datang sedangkan sapa diberikan kepada wisatawan setelah datang. Sapa ini dilakukan agar memberikan kesan perhatian, tidak cuek kepada wisatawan. Kegiatan sapa ini memang hal yang biasa diremehkan, namun sangat memberikan kesan yang positif. Sapa bisa dilakukan saat wisatawan sedang bersantai dilokasi, atau pada saat wisatawan akan pulang. Contoh kalimat sapa kepada wisatawan saat ada dilokasi, "Selamat siang / selamat sore, bagaimana ibu selama berwisata di Teluk Love? Apakah ada kekurangan" atau bisa juga dengan kalimat sapaan. "Selamat siang / selamat sore ibu, adakah yang bisa saya bantu" kalimat ini bisa diucvapkan ketika melihat wisatawan seperti sedang kebingungan. Jika wisatawan akan pulang, kalimat sapa yang bisa diucapkan adalah, "Selamat siang / selamat sore. Terima kasih sudah datang ke Teluk Love, Semoga dapat datang kembali".

Pada saat bertemu dengan wisatawan, sumber daya manusia yang ada baik masyarakat maupun pengelola Teluk Love diusahakan jangan memasang wajah cemberut, wajah masam dan wajah yang sedang marah, karena hal ini akan menimbulkan kesan tidak ramah kepada wisatawan. Raut wajah diusahakan agar bisa selalu tersenyum, walaupun kondisi badan sedang lelah ataupun sedang dalam masalah, tidak diperkenankan memperlihatkan raut muka masam. Efek dari memberikan senyuman kepada wisatawan, selain memberikan kesan ramah juga berfungsi untuk merubah suasana hati yang sedang tidak baik. Membantu wisatawan untuk bisa merasakan aura positif yang menyenangkan selama berwisata di Teluk Love, sehingga wisatawan akan merasakan suasana hati yang menyenangkan setelah menikmati keindahan Teluk Love. Kesan yang menyenagkan inilah yang membuat wisatawan akan datang lagi dan lagi.

Setelah melakukan salam, sapa dan senyum, dalam aplikasinya memang tidak terbilang mudah. Harus memperhatikan dari segi kesopanan, contohnya adalah pada saat mengucapkan salam harus memilih kata - kata yang tepat, kontak mata yang dilakukan juga harus dilakukan dengan tepat, pada saat berbicara hendaknya menatap wajah lawan 
bicara bukan memperhatikan keadaan sekitar, sehingga wisatawan merasa dihargai. Begitu pula dengan gestur badan yang diperlihatkan, diusahakan agar tidak memberikan gestur badan bungkuk, kaki menyilang, atau bahkan memberikan tatapan yang meremehkan. Pada saat melakukan kalimat sapaan juga harus memperhatikan nada suara, tidak terlalu rendah maupun terlalu tinggi.

Sentuh disini maksudnya adalah melakukan kontak kulit seperti berjabat tangan. Jabat tangan bisa dilakukan sebagai simbol penghargaan kepada wisatawan, dengan mengucapkan terima kasih telah berkunjung ke pantai teluk Love.

Setelah memberikan pemaparan materi $5 \mathrm{~S}$ ini, peserta yang terdiri dari perwakilan masyarakat, tokoh masyarakat dan anggota pokdarwis untuk berlatih melakukan 5S, yang nantinya bisa dipraktekkan langsung kepada wisatawan yang datang. Diharapkan dengan pelatihan $5 \mathrm{~S}$ ini, dapat memberikan pelayanan yang optimal kepada wisatawan demi memberikan rasa nyaman kepada wisatawan.

\subsection{Pelatihan Sadar Wisata}

Sadar Wisata dapat didefinisikan sebagai sebuah konsep yang menggambarkan partisipasi dan dukungan segenap komponen masyarakat dalam mendorong terwujudnya iklim yang kondusif bagi tumbuh dan berkembangnya kepariwisataan di suatu wilayah dan bertujuan untuk meningkatkan kesejahteraan rakyat. Sadar Wisata sangat berkaitan dengan Sapta Pesona(Utami \& Rahman, 2017) , karena sadar wisata dapat diwujudkan dengan menjalankan Sapta Pesona, sehingga jika masyarakat telah sadar wisata dan telah menjalankan konsep sapta pesona maka wisatawan akan tertarik mengunjungi daerah tujuan wisata (Murianto \& Masyhudi, 2017). Tujuh aspek pelatihan Sapta Pesona di kawasan Pantai Teluk Love adalah:

(1) Aman; sebagian kecil wisatawan masih merasa kurang aman saat mereka tiba di kawasan pantai Teluk Love, dikarenakan banyak masyarakat yang menawarkan tempat parkir untuk kendaraan roda dua dan empat, yang jaraknya cukup jauh untuk ditempuh dengan berjalan kaki menuju pintu gerbang pantai Teluk Love. Tim dalam hal ini telah memberikan pengetahuan dan sosialisasi tentang keamanan kepada Pokdarwis MASSAWI salah satunya dengan cara menyediakan lahan parkir yang aman, tertib dan rapi;

(2) Tertib, Tim telah mensosialisasikan kepada Pokdarwis MASSAWI untuk mendata para wisatawan dengan rapi dan tertib administrasi. Selain itu mereka juga membuat tiket masuk untuk mengetahui jumlah wisatawan yang berkunjung agar sesuai dengan data pengunjung yang telah tercatat di buku tamu. Tim juga telah mensosialisasikan kepada Pokdarwis MASSAWI untuk menambah papan penunjuk arah di sepanjang jalur trekking di bukit Teluk Love, dimana para wisatawan harus memulai dan mengakhiri aktifitas trekkingnya sampai kembali lagi ke gazebogazebo tempat peristirahatan yang berada di sekitar pantai Teluk Love. Tim juga telah membagikan kaos seragam kepada semua anggota Pokdarwis MASSAWI untuk digunakan sesuai jadwal yang sudah ditentukan untuk membedakan mana yang petugas dan wisatawan;

(3) Bersih; tim telah memberikan sosialisasi kepada Pokdarwis MASSAWI untuk menambah petugas kebersihan dan menyediakan lebih banyak tempat sampah yang dibedakan menjadi dua (sampah organik dan non organik). Tim juga memberikan pemahaman tentang pentingnya kebersihan di Pantai Teluk Love dengan cara menerapkan prinsip zero waste;

(4) Sejuk; tim telah memberikan pemahaman tentang pentingnya menambah jumlah jenis pohon dan tanaman yang dapat ditanam di sekitar kawasan Pantai Teluk Love. Hal ini bertujuan untuk menciptakan suasana yang 
sejuk bagi wisatawan. Selain itu, tim juga menghimbau Pokdarwis MASSAWI untuk membangun tempat-tempat berteduh bagi wisatawan di beberapa titik di sepanjang jalur trekking di Bukit Teluk Love;

(5) Indah; tim telah memberikan sosialisasi kepada seluruh anggota Pokdarwis MASSAWI untuk menghalau hewan-hewan yang berkeliaran di sekitar kawasan wisata Pantai Teluk Love, seperti kambing, dan anjing. Tim juga telah mensosialisasikan kepada Pokdarwis MASSAWI untuk menghilangkan semua benda yang mengahalangi wisatawan saat menikmati keindahan sunrise dan sunset di Bukit Teluk Love;

(6) Ramah; Tim dalam hal ini telah mengingatkan seluruh anggota Pokdarwis MASSAWI agar selalu bersikap ramah terhadap setiap wisatawan yang datang ke Pantai Teluk Love. Seluruh anggota Podarwis MASSAWI diharapkan dapat mengaplikasikan prinsip 5S yang telah diberikan. Hal ini penting karena dapat memberikan kesan ramah kepada wisatawan;

(7) Kenangan; Untuk aspek kenangan, tim telah meminta Pokdarwis MASSAWI untuk membuat stand khusus oleh-oleh maupun toko souvenir yang iconic dari Pantai Teluk Love. Hal ini diharapkan dapat menjadi cirikhas yang mampu menjadi kenangan bagi wisatawan setelah mereka meninggalkan Pantai Teluk Love.

\subsection{Pelatihan Manajemen dan Organisasi Bentuk Organisasi}

Pada umumnya strategi organisasi mempengaruhi struktur organisasi. Dan jenis struktur organisasi akan mempengaruhi Sistem Pengendalian Manajemen. Struktur organisasi dapat dikelompokkan menjadi tiga katagori, yaitu:

1) Organisasi Fungsional, setiap manajer bertanggungjawab pada fungsi organisasi, misalnya produksi, pemasaran.
2) Organisasi unit bisnis, setiap manajer mempertanggungjawaban aktivitas unitnya, dan unit bisnis merupakan bagian organisasi yang semi independent.

3) Organisasi matrix, setiap fungsi mempunyai tanggung jawab ganda

Bentuk implementasi struktur organisasi pada Pokdarwis Massawil yaitu Organisasi Unit Bisnis atau juga disebut Divisi, mempertanggungjawabkan semua fungsi yang terdiri dari fungsi pelayanan dan pemasaran untuk setiap lini produk. Mereka bertanggung jawab untuk melakukan kegiatan perencanaan, koordinasi dari setiap fungsi yang berbeda.

Sistem pengendalian Manajemen yang baik adalah system yang selaras dengan goal congruence dalam organisasi, yaitu suatu kondisi yang diperoleh dari usaha anggota organisasi dalam mencapai goal nya masingmasing juga membantu tercapainya goal organisasi. Untuk memahami konsep goal congruence, perlu diketahui faktor yang mempengaruhi goal congruence, yaitu system formal dan informal. Sistem formal dikelompokkan menjadi: aturan dan metode sistematis dalam perencanaan dan pengendalian.

Organisasi mempunyai tujuan, manajer maupun pimpinan puncak akan berusaha untuk mencapai tujuan tersebut bersama anggota organisasi lainnya. Sebaliknya anggota organisasi mempunyai tujuan yang bervariasi yang belum tentu sama denga tujuan organisasi. Tujuan utama dari Sistem Pengendalian Manajemen untuk mengupayakan terjadinya "Goal Congruence". Dalam proses Goal Congruence, tindakan yang dilakukan anggota organisasi ditujukan untuk mencapai tujuan individu yang juga memberi manfaat pada organisasi.

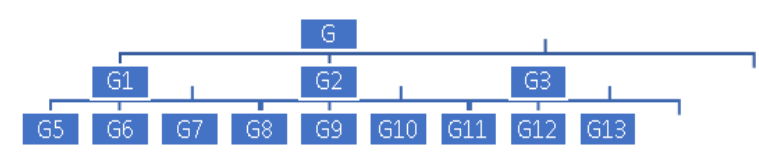


Gambar 3. Konsep Mean-end analysis

Dalam pengendalian manajemen akan berusaha mendorong anggota organisasi melakukan kegiatan untuk kepentingan organisasi, untuk itu pimpinan harus dapat melakukan:

1) Tindakan yang dapat memotivasi anggota organisasi melakukan usaha untuk memenuhi tujuannya (individu)

2) Tindakan tersebut juga mempunyai kontribusi pada kepentingan organisasi.

Norma mengenai perilaku yang diyakini dalam suatu lingkungan social dimana organisasi berada. Norma ini termasuk beberapa atitut, yang tercermin pada etika kerja, yang mendorong karyawan loyal, membuat mereka bangga menjadi bagian dari organisasi. Faktor internal yaitu kultur dn gaya kepemimpinan.

Terdapat tiga bentuk kepimpinan yaitu:

a) Internal Control Style, yaitu kepemimpinan yang memberikan kesempatan semua anggota organisasi untuk berpartisipasi dalam menentukan kegiatan yang akan dilakukan untuk mencapai tujuan.

b) Eksternal Control Style, yaitu kepemimpinan yang bersifat otoriter, jadi semua keputusan mengenai tindakan yang akan dilakukan ditentukan oleh pimpinan.

c) Mixed Control Style, yaitu kombinasi antara internal dan eksternal Control style, setiap anggota organisasi mempunyai kesempatan berpartisipasi tetapi masih diarahkan dari pimpinan.

Dalam Struktur organisasi, Controller merupakan fungsi Staff. Meskipun Controler bertanggung jawab untuk merancang dan menjalankan system untuk memperoleh informasi, pemakai informasi tersebut adalah manajer yang ada dalam struktur. Controler bertanggung jawab menetapkan dan menganalisa pengukur pengendalian dan memberkan rekomendasi tindakan yang harus dilakukan. Keputusan yang dilakukan controller adalah mengenai implementasi kebijakan yang ditetapkan manajer, Controller juga mempunyai peran penting dalam menetapkan program yang akan dijalankan beserta anggaran.

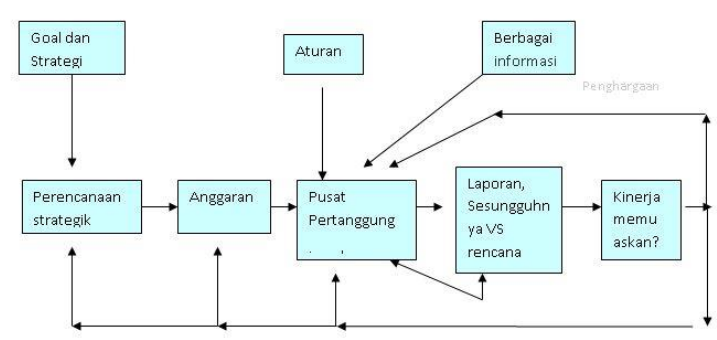

Gambar 4. Proses Pengendalian formal

Controller unit bisnis mempunyai dua pimpinan, yaitu corporate controller yang bertanggung jawab pada system pengendalian secara keseluruhan dalam organisasi dan disisi lain dia juga mempunyai tanggung jawab pada manajer unit bisnis yang dibantunya. Pada beberapa organisasi controller divisi melaporkan tugasnya pada manajer unit bisnis dan hubungannya dengan corporate controller tidak langsung. Ada juga organisasi yang menetapkan controller divisi melaporkan tugasnya pada corporate controller.

Controller unit bisnis mempunyai dua pimpinan, yaitu corporate controller yang bertanggung jawab pada system pengendalian secara keseluruhan dalam organisasi dan disisi lain dia juga mempunyai tanggung jawab pada manajer unit bisnis yang dibantunya. Pada beberapa organisasi controller divisi melaporkan tugasnya pada manajer unit bisnis dan hubungannya dengan corporate controller tidak langsung. Ada juga organisasi yang menetapkan controller divisi melaporkan tugasnya pada corporate controller. 


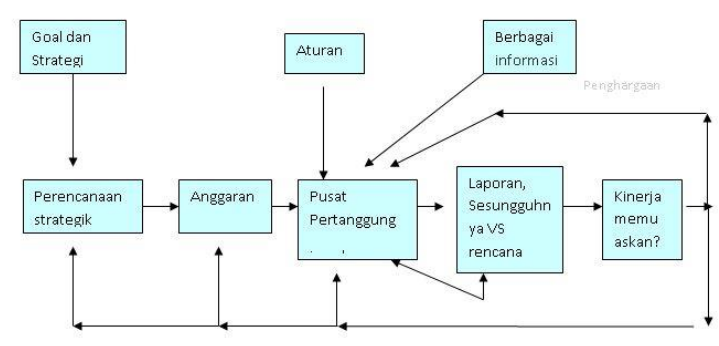

Gambar 5. Controller Unit Bisnis

\section{KESIMPULAN}

Kegiatan Pengabdian Kepada Masyarakat di telok love dengan melibatkan Pokdarwis Massawi (kelompok sadar wisata masyarakat sadar wisata bahari) tim pengabdian telah memberikan pelatihan mengenai pelatihan soft skill Sumber daya manusia 5S (Salam, Sapa, Senyum, Sopan, Sentuh), Pelatihan Sadar Wisata dan Sapta Pesona (Aman, Tertib, Bersih, Sejuk, Indah, Ramah, dan Kenangan) dan Pelatihan manajemen organisasi. Pelatihan selanjutnya adalah "human packaging" dan "spot selfie packaging". Human packaging bertujuan agar pengelola Teluk Love memiliki sebuah kemasan yang mencirikan jati diri, dengan cara pemberian seragam yang bernuansa Teluk Love untuk seluruh anggota pokdarwis yang saat ini bertanggungjawab untuk mengelola Teluk Love. Spot selfie packaging adalah pembuatan tempat berfoto di spot terbaru

Tuntutan dari perkembangan pariwisata zaman sosial media Pengembangan yang dapat dilanjutkan adalah pengembangan tempat wisata Teluk Love dengan sentuhan modern, penambahan spot wisata, cenderamata, dan kerjasama antara pengelola wisata, dinas terkait, Pemerintah Kabupaten Jember maupun pemerintahan melalui kementrian pariwisata untuk saling bersinergi. Selain hal tersebut juga, untuk menjaga keberlangsungan usaha, perusahaan sangat perlu untuk lebih agresif memperkenalkan produk usahanya dengan prinsip 5S. Sapta Pesona yang murah, efektif dengan pemanfaatan baik media off line maupun online secara contiuously.

\section{DAFTAR PUSTAKA}

Cooper, C., \& Hall, C. M. (2008). Contemporary tourism: An international approach. Routledge.

Murianto, \& Masyhudi, L. (2017). Pemahaman dan Penerapan Sapta Pesona Pada. Pokdarwis di Wisata di Pantai Surga, Desa Ekas, Kabuparen Lombok Timur. Media. Bina Ilmiah, 11(6).

Savitri, S. N. (2018). Upaya Pemerintah Dalam Menjalankan Sapta Pesona Pariwisata Di Kabupaten Magetan. Journal of Politic and Government Studies, 8(1), 181-190.

Septio, A., Karyani, T., \& Djuwendah, E. (2019). Visitors Perception About The Sapta Pesona Implementation In Kampung Flory Sleman Yogyakarta. Journal of Business on Hospitality and Tourism, 5(2), 307. https://doi.org/10.22334/jbhost.v5i2.174

Sukarni. (2019). Implementasi Pendidikan Karakter Melalui Program 5s (Senyum, Salam, Sapa, Sopan, Santun) Dalam Membentuk Akhlak Islami Siswa Di Mi Al-Marifatul Islamiyah Dasan Agung Kota Mataram Tahun Ajaran 2018/2019. Universitas Muhammadiyah Mataram.

Utami, A. N., \& Rahman, A. Z. (2017). Pelaksanaan Progam Kampanye Sadar Wisata dan Sapta Pesona melalui Pelestarian Kelompok Sadar Wisata (Pokdarwis) di Kelurahan Kandri Kecamatan Gunungpati Kota Semarang. Journal of Public Policy and Management Review, 6(2), 591-606. 